\title{
New Afrotropical species of Tenuopus Curran, 1924 (Diptera: Dolichopodidae)
}

\section{Новые виды Tenuopus Curran, 1924 (Diptera: Dolichopodidae) из Тропической Африки}

\author{
I.Ya. Grichanov \\ И.Я. Гричанов
}

\begin{abstract}
All-Russian Institute of Plant Protection, Podbelskiy roadway 3, St. Petersburg-Pushkin, 196608 Russia. E-mail: grichanov@mail.ru Всероссийский институт защиты растений, шоссе Подбельского 3, Санкт-Петербург-Пушкин, 196608, Россия.
\end{abstract}

KEY WORDS: Diptera, Dolichopodidae, Tenuopodinae, Tenuopus, taxonomy, new species, new record, Tropical Africa.

КЛЮЧЕВЫЕ СЛОВА: Diptera, Dolichopodidae, Tenuopodinae, Tепиориs, таксономия, новый вид, новое указание, Тропическая Африка.

ABSTRACT: A new material for the Afrotropical genus Tenuopus Curran, 1924 has been recently found and identified. Tenuopus comorensis Grichanov, sp.n. from Comoros and T. birketti Grichanov, sp.n. from Mozambique and South Africa are described and illustrated. New species differ from other representatives of the genus in morphology of male genitalia mainly. A new record is given for the known species, T. kylei Grichanov, 2018. Corrections of the last key to species of Tenuopus are also provided.

РЕЗЮМЕ: Обнаружен и определён новый материал для афротропического рода Тепиориs Curran, 1924. Описаны Tenuориs comorensis Grichanov, sp.n. с Коморских островов и T. birketti Grichanov, sp.n. из Мозамбика и Южной Африки. Новые виды отличаются от известных, главным образом, по морфологии гениталий самцов. Приведён новый материал для T. kylei Grichanov, 2018. Даны дополнения к последнему определителю видов рода.

The Afrotropical genus Tenuopus Curran, 1924 has been recently revised by Grichanov [2018], who has created a new monotypic subfamily Tenuopodinae for the genus and provided a key for 19 known species. A careful sorting of Malaise traps' residues from two collections has revealed new material showing much more diverse fauna of this group in southern Africa.

In this paper two new species of Tепиориs, T. comorensis Grichanov, sp.n. from Comoros and T. birketti Grichanov, sp.n. from Mozambique and South Africa are described. The present research gives also a new record for the known species, T. kylei Grichanov, 2018. Now five Tenuopus species are found in South Africa and two species in Mozambique. In total, 21 species of the genus are now known. T. comorensis is the fifth dolichopodid species discovered on the Comoros, with all the species being Island endemics.

Material cited in this work is housed at the Natal Museum, Pietermaritzburg, Kwa-Zulu Natal, South Africa (NMSA) and Zoologische Staatssammlung, München, Germany (ZSM). Specimens have been studied and photographed with a ZEISS Discovery V-12 stereo microscope and an AxioCam MRc5 camera. Genitalia preparations have been photographed with a ZEISS Axiostar stereo microscope and an AxioCam ICc3 camera. Morphological terminology and abbreviations follow Cumming and Wood [2017], and Grichanov, Brooks [2017]. The relative lengths of the antennomeres and podomeres should be regarded as representative ratios and not measurements. Body length is measured from the base of the antenna to the tip of abdominal segment 6 . Wing length is measured from the base to the wing apex. The figures showing the hypopygium in lateral view are oriented as it appears in the intact specimens, with the morphologically ventral surface of the genitalia facing upwards, dorsal surface downwards, anterior end facing left and posterior end facing right.

\section{Tenuopus comorensis Grichanov, sp.n.}

Figs 1-2.

MATERIAL. Holotype $\sigma^{7}$ (dried from ethanol and mounted on pin), [Comoros:] Comoren, Grand Comore, bergauf von Bahani, 12.IV.2002, M. Kotrba (ZSM).

DESCRIPTION. Male (somewhat discolorated). Head. Frons black, grey pollinose; one pair of short postvertical setae, shorter than uppermost postocular seta; upper postocular setae black, increasing in length upward; lateral and lower postoculars white; ventral postcranium covered with irregular white hairs; face silvery-white, 7 times as high as wide in middle, nearly as wide as postpedicel; clypeus bulg-

How to cite this article: Grichanov I.Ya. 2019. New Afrotropical species of Tenuopus Curran, 1924 (Diptera: Dolichopodidae) // Russian Entomol. J. Vol.28. No.4. P.460-463. doi: 10.15298/rusentj.28.4.15 
ing; antennae as long as height of head, yellow; pedicel projected distally on inner side, with a crown of short black setae, one of dorsal setae nearly as long as pedicel; postpedicel rounded, as long as high at base (20/17); arista-like stylus dorsal, with short hairs; length ratio of scape to pedicel to postpedicel to stylus ( $1^{\text {st }}$ and $2^{\text {nd }}$ segments), $11 / 15 / 20 / 10 / 73$; palpus and proboscis short, yellow, covered with white hairs, proboscis also with a pair of black lateral setae.

Thorax. Pleura dirty yellow; mesonotum orange, with narrow brown stripe along acrostichals, wider posteriorly and brown on scutellum dorsally; 6 dorsocentral setae with posterior pair shifted laterally; acrostichals regularly biseriate, strong, nearly reaching $5^{\text {th }}$ dorsocentrals; scutellum with 2 strong bristles and 2 short lateral hairs; proepisternum with 2 yellow setae.

Legs. Yellow; last segments of tarsi brown; fore and mid coxae with black hairs anteriorly and 5-7 black apical bristles of various length; hind coxa with one long black outer bristle above middle; fore femur with only dark fine erect ventral hairs on basal half, and 3 short black posteroventral cilia; fore tibia simple, with 1 anterodorsal and 1 posterodorsal at base, 2 apical setae; $2^{\text {nd }}$ segment of fore tarsus on distal third and $3^{\text {rd }}$ segment on basal half with posteroventral row of short semierect setulae; claws simple; mid femur without anterior preapical seta, with anteroventral row of black erect hairs, about half as long as diameter of femur; mid tibia with 3 anterior, 3

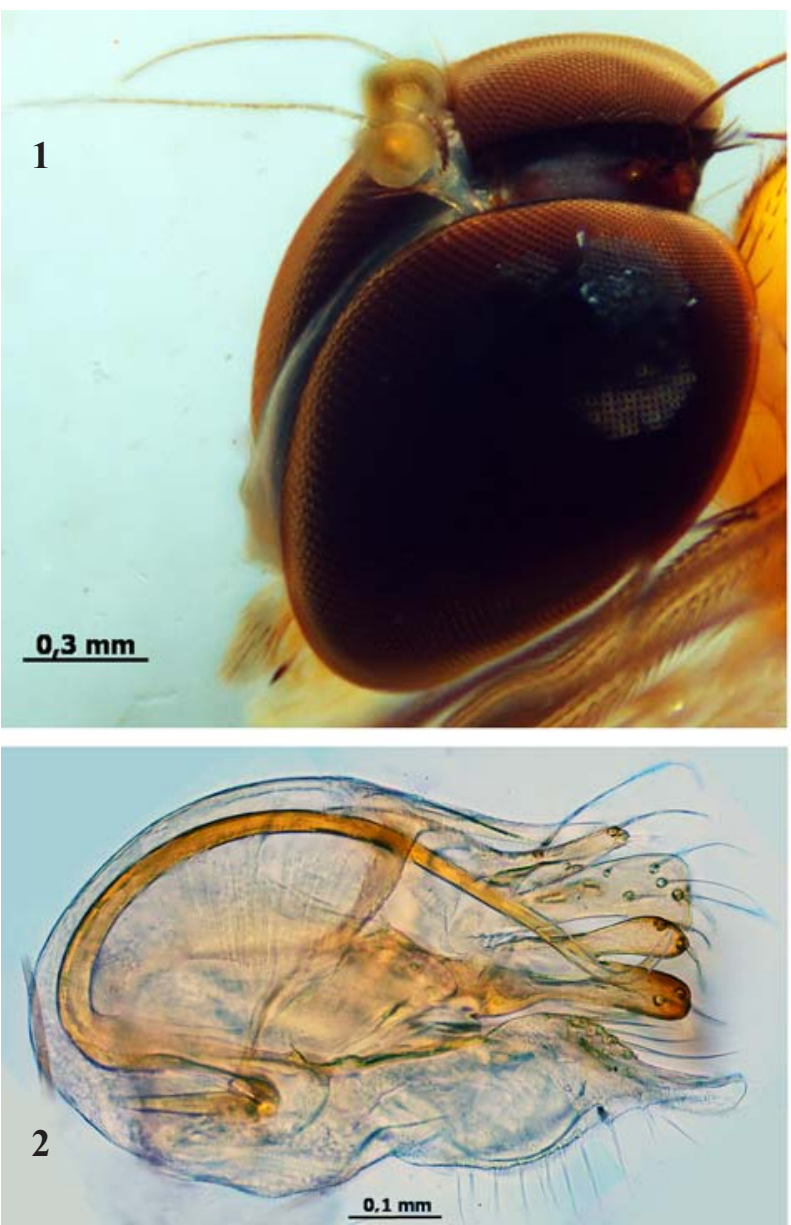

posterodorsal, 3-4 short ventral, 4-5 apical setae; mid basitarsus with several short ventral setae; hind femur ventrally with black erect hairs, about one-third as long as diameter of femur, with 1 strong anterior preapical seta; hind tibia with 4 anterior, 4 posterodorsal, 3-4 apical setae. Femur, tibia and tarsomere (from first to fifth) length ratio (in $\mathrm{mm}$ ): fore leg: 1.85/1.98/1.69/1.13/0.86/0.59/0.31, mid leg: 1.86/2.79/2.07/ 0.96/0.76/0.45/0.19, hind leg: $2.45 / 3.81 / 1.26 / 1.25 / 0.80 / 0.49 /$ 0.24 .

Wing. Greyish, almost hyaline, veins brown; subcosta very thin; ratio of part of costa between $R_{2+3}$ and $R_{4+5}$ to that between $R_{4+5}$ and $M_{1}, 6 / 1 ; M_{1}$ with gentle arc to apex, reaching costa right before wing apex; $\mathrm{M}_{2}$ present as fold on membrane; cross-vein $d m$ - $m$ straight; ratio of crossvein $d m-m$ to apical part of $\mathrm{M}_{1+2}$ (fork-handle) to apical part of $\mathrm{M}_{4}, 0.37 /$ 1.12/0.85; anal vein foldlike, not reaching wing margin; anal angle obtuse; lower calypter yellow, with black apex and pale setae; halter yellow with orange knob, halter stem thin and long, with dorsal and ventral groups of short hairs distally.

Abdomen. Mostly yellow-orange, black setose; $1^{\text {st }}$ segment yellow, with narrow brown posterior edging; $2^{\text {nd }}-5^{\text {th }}$ yellow, with narrow brown edging posteriorly and anteriorly; $6^{\text {th }}$ mostly brown; $8^{\text {th }}$ segment and epandrium entirely yellow; $8^{\text {th }}$ segment with brownish setae; cercus and surstylus yellow; cercus covered with yellow hairs and setae; hypandrium small, simple; phallus thin and simple; 2 long epandrial lobes

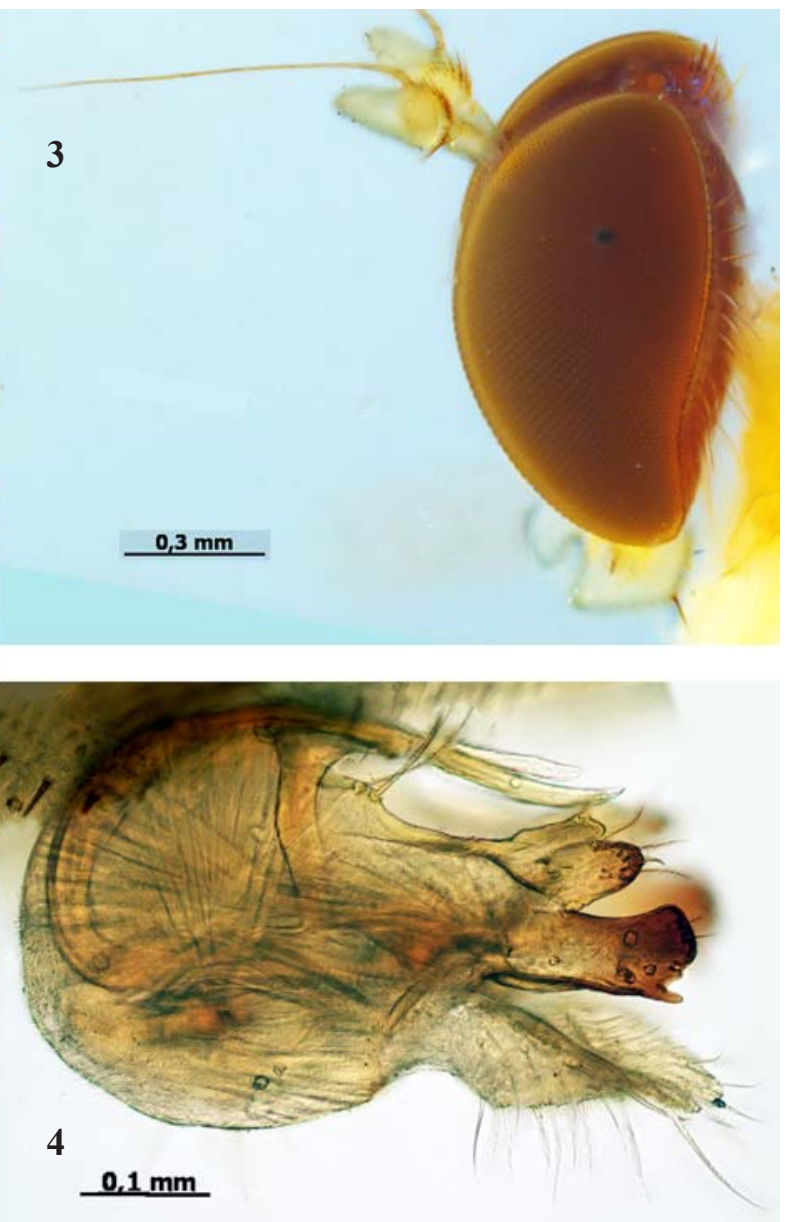

Figs 1-4. Tenuopus spp., males: 1-2 - T. comorensis Grichanov, sp.n.; 3-4 T. birketti Grichanov, sp.n.; 1, $3-$ head; 2, $4-$ hypopygium, lateral view.

Рис. 1-4. Тепиориs spp., самцы: 1-2 - T. comorensis Grichanov, sp.n.; 3-4 - T. birketti Grichanov, sp.n.; 1, 3 - голова; 2, $4-$ гипопигий, сбоку. 
distally on each side; thin epandrial lobe with 1 basal and 1 apical long setae, with 3 short setae; thick epandrial lobe expanded distally, with 5 setae at apex; surstylus slightly shorter than cercus, divided in 2 subequal lobes from middle, with 2 setae at apex of each lobe; cercus half as long as epandrium, elongate, with narrow distal process, covered with long setae dorsally and ventrally.

Measurements (in $\mathrm{mm}$, in ethanol). Body length 7.0, antenna length 1.2 , wing length 5.7 , wing width 1.6 .

Female. Unknown.

ETYMOLOGY. The species is named after the Comoro Islands.

DISTRIBUTION. Comoros.

DIAGNOSIS. T. comorensis sp.n. belongs to a group of species with biseriate acrostichals, being the closest to $T$. gorongosaensis Grichanov, 2018 and T. kirkspriggsi Grichanov, 2018, differing in ciliation of fore leg and morphology of hypopygial appendages (see key below).

16. Cercus spatulate, slightly expanded distally; surstylus about as long as cercus, divided in 2 lobes from base; $3^{\text {rd }}$ to $5^{\text {th }}$ segments of fore tarsus with posteroventral row of short semi-erect setulae ........... T. gorongosaensis Grichanov

- Cercus swollen at base, narrow at apex; other features various ................................................................. 16a

16a. Fore tibia with elongate ventral hairs and posterior setulae; fore tarsomeres covered with dense hairs ventrally and elongate setulae dorsally; surstylus about half as long as cercus, simple .......... T. kirkspriggsi Grichanov

- Fore tibia without elongate hairs and setulae; $2^{\text {nd }}$ segment of fore tarsus on distal third and $3^{\text {rd }}$ segment on basal half with posteroventral row of short semi-erect setulae; surstylus about as long as cercus, divided in 2 lobes from middle T. comorensis sp.n.

\section{Tenuopus birketti Grichanov, sp.n. Figs 3-4.}

MATERIAL. Holotype $\sigma^{\top}$, Mozambique: [Maputo Province,] Ponta Milibangalala, 24-30.VI.2006, P. Birkett (NMSA); paratypes: $20^{2}, 49$, same label (NMSA; holotype and 19 paratype are dried from ethanol and mounted on pin); 107, South Africa: KZN [KwaZulu Natal], Kosi Bay (2632DD), 30.XI-12.XII [1982?] (NMSA; in glycerol in 2 vials mounted on pin).

DESCRIPTION. Male (somewhat discolorated). Head. Frons shining violet-black, weakly pollinose; one pair of short postvertical setae, shorter than uppermost postocular seta; upper postocular setae black, increasing in length upward; lateral and lower postoculars white; ventral postcranium covered with irregular white hairs; face silvery-white, 7 times as high as wide in middle, nearly as wide as postpedicel; clypeus slightly bulging; antennae as long as height of head, yellow; pedicel projected distally on inner side, with a crown of short black setae, one of dorsal setae nearly as long as pedicel; postpedicel elongate-ovate, longer than high at base (23/14); arista-like stylus dorsal, with short hairs; length ratio of scape to pedicel to postpe-dicel to stylus ( $1^{\text {st }}$ and $2^{\text {nd }}$ segments), 10/11/23/5/80; palpus and proboscis short, yellow, covered with white hairs, proboscis also with a pair of black lateral setae.

Thorax. Pleura dirty yellow; mesonotum orange, with brown-black stripe along acrostichals, wider posteriorly and brown on scutellum dorsally; 6 dorsocentral setae with $1^{\text {st }}$ pair small and posterior pair shifted laterally; acrostichals practically absent, few setae on anterior slope and 2 setae in middle; scutellum with 2 strong bristles and 2 short lateral hairs; proepisternum with 2 yellow setae.
Legs. Yellow; last segments of tarsi brown; fore coxa with white hairs anteriorly and 3 black apical bristles; mid coxa with black hairs anteriorly and 5-7 black apical bristles of various length; hind coxa with one long black outer bristle above middle; fore leg devoid of bristles and remarkable hairs; claws simple; mid femur with anterior preapical seta, glabrous ventrally; mid tibia with 2 long and 1 short anterior, 3 short posterodorsal, 2-3 short ventral, 4-5 apical setae; hind femur ventrally with simple setulae, with 1 strong anterior preapical bristle; hind tibia with 2-3 anterior, 4 short posterodorsal, 3-4 apical setae. Femur, tibia and tarsomere (from first to fifth) length ratio (in $\mathrm{mm}$ ): fore leg: 1.02/1.09/ 1.06/1.60/0.47/0.24/0.14, mid leg: 1.27/1.90/1.17/0.57/0.45/ $0.26 / 0.15$, hind leg: $1.48 / 2.50 / 0.58 / 0.77 / 0.46 / 0.27 / 0.15$.

Wing. Evenly coloured, almost hyaline, veins yellow; subcosta very thin; ratio of part of costa between $R_{2+3}$ and $R_{4+5}$ to that between $R_{4+5}$ and $M_{1}, 6 / 1 ; M_{1}$ with gentle arc to apex, reaching costa right before wing apex; $M_{2}$ present as fold on membrane; cross vein $d m$ - $m$ straight, oblique; ratio of crossvein $d m-m$ to apical part of $\mathrm{M}_{1+2}$ (fork-handle) to apical part of $\mathrm{M}_{4}, 0.24 / 0.85 / 0.84$; anal vein foldlike, not reaching wing margin; anal angle obtuse; lower calypter yellow, with dark apex and pale setae; halter yellow, halter stem thin and long, with dorsal and ventral groups of short hairs distally.

Abdomen. Mostly yellow-orange, black setose; $1^{\text {st }}$ segment yellow; $2^{\text {nd }}-5^{\text {th }}$ yellow, brown dorsally at posterior suture; $8^{\text {th }}$ segment and epandrium entirely yellow; $8^{\text {th }}$ segment with yellow and brownish setae; cercus and surstylus yellow; surstylus brown distally; cercus covered with yellow hairs and setae; hypandrium small, simple; phallus thin and simple; 2 epandrial lobes distally on each side; thick epandrial lobe with 5-6 apical setae; thin epandrial lobe with 2 apical setae; 2 long epandrial setae at base of hypandrium; surstylus nearly as long as cercus, simple, with short subapical dorsal tooth, with 2 short apical setae; cercus half as long as epandrium, swollen basally, narrow distally, covered with long setae dorsally and distally.

Measurements (in mm, in ethanol). Body length 4.2-4.8, antenna length 1.0 , wing length $3.6-4.7$, wing width $1.0-1.2$.

Female. Similar to male except lacking male secondary sexual characters. Frons shining blue; face nearly parallelsided, 4 times as high as wide in middle; postpedicel subtriangular, with rounded apex, as long as high at base (15/13); length ratio of scape to pedicel to postpedicel to stylus $\left(1^{\text {st }}\right.$ and $2^{\text {nd }}$ segments), $15 / 11 / 15 / 6 / 102 ;$ mesonotum with shining green stripe along acrostichals; tibia and tarsomere (from first to fifth) length ratio (in $\mathrm{mm}$ ): fore leg: 1.02/1.09/1.06/1.60/ 0.47/0.24/0.14, mid leg: 1.27/1.90/1.17/0.57/0.45/0.26/0.15, hind leg: $1.48 / 2.50 / 0.58 / 0.77 / 0.46 / 0.27 / 0.15 ; 7^{\text {th }}$ segment of abdomen brown; oviscapt small; terga 9+10 divided medially into 2 hemitergites, each bearing 5 long simple setae; anal plate weakly sclerotized, semicircular, adjacent to lateral processes covered with long hairs.

Measurements (in mm, in ethanol). Body length 4.5-5.2; wing length 3.9-4.2.

ETYMOLOGY. The species is named after the South African entomologist, P. Birkett (NMSA), the collector of the type specimens.

DIAGNOSIS. T. birketti sp.n. is the smallest fly in the genus and belongs to a group of species with uniseriate acrostichals or without acrostichals, being the closest to $T$. soderlundi Grichanov, 2018, differing from the latter in antennal postpedicel about 2 times as long as high and different morphology of epandrial lobes and surstylus. $T$. soderlundi has antennal postpedicel about as long as high. Both species differ from T. cognatus Parent, 1934 in abdo- 
men with $2^{\text {nd }}-5^{\text {th }}$ segments almost entirely yellow and deeply furcated surstylus with narrow arms (see key below). $T$. birketti sp.n. female differs from T. cognatus and T. erroneus Parent, 1934 in abdomen with $3^{\text {rd }}-5^{\text {th }}$ segments almost entirely yellow (see key below).

\section{Males}

8. Abdomen with $2^{\text {nd }}-5^{\text {th }}$ segments mostly yellow orange, each with broad black posterior triangular spot; $M_{4} 3$ times longer than $d m-m$; antennal postpedicel as long as high; surstylus deeply furcated with narrow arms; body length $6 \mathrm{~mm}$ T. cognatus Parent

- Abdomen with $2^{\text {nd }}-5^{\text {th }}$ segments almost entirely yellow; $\mathrm{M}_{4}$ usually 4 times longer than $\mathrm{dm}-\mathrm{m}$; surstylus not furcated $8 \mathrm{a}$

8a. Antennal postpedicel as long as high; body length 5-5.2 $\mathrm{mm}$ T. soderlundi Grichanov

- Antennal postpedicel about 2 times as long as high; body length $4.2-4.8 \mathrm{~mm}$ T. birketti sp.n. Females

22. Hind tarsus entirely black; $\mathrm{R}_{4+5}$ and $\mathrm{M}_{1}$ reaching costa at wing apex T. cognatus Parent

- Hind tarsus yellow at base; $M_{1}$ reaching costa before wing apex $22 \mathrm{a}$

22a. Abdomen with $3^{\text {rd }}-5^{\text {th }}$ segments each with large blueblack posterior spots T. erroneus Parent

- Abdomen with $3^{\text {rd }-5^{\text {th }}}$ segments each with narrow brown posterior bands T. birketti sp.n.
REMARKS. T. birketti sp.n. male from Kwa-Zulu Natal is remarkable in its smallest size, with wing length $3.6 \mathrm{~mm}$, differing also from the Mozambiquean material in the reduction of some bristles on legs. Hypopygia of the two forms are identical; therefore, I consider their difference as an intraspecific variation. The collection sites for the two populations are located at a distance about $30-40 \mathrm{~km}$ from each other.

Tenuopus kylei Grichanov, 2018

MATERIAL. 207, 2q, South Africa: KZN [Kwa-Zulu Natal], Kosi Bay (2632DD), 30.XI-12.XII [1982?] (NMSA).

DISTRIBUTION. South Africa (Kwa-Zulu Natal).

\section{References}

Cumming J.M., Wood D.M. 2017. 3. Adult morphology and terminology // Kirk-Spriggs A.H., Sinclair B.J. (eds.). Manual of Afrotropical Diptera. Vol.1. Nematocerous Diptera and lower Brachycera. Suricata 4. Pretoria: SANBI Graphics and Editing. P.89-134.

Grichanov I.Ya. 2018. A new subfamily of Dolichopodidae (Diptera) for Тепиориs Curran, 1924 with description of new species from Tropical Africa // Far Eastern Entomologist. No.364. P.1-25. Doi.org/10.25221/fee.365.1.

Grichanov I.Ya., Brooks S.E. 2017. 56. Dolichopodidae (longlegged dance flies) // Kirk-Spriggs A.H., Sinclair B.J. (eds.). Manual of Afrotropical Diptera. Vol.2. Nematocerous Diptera and lower Brachycera. Suricata 5. Pretoria: SANBI Graphics and Editing. P.1265-1320. 